\title{
The Meanings of the Preposition "BY" in the IX-XIX Centuries with Their Azerbaijani Equivalents
}

\author{
Aliyeva Shalalah Anvar ghizi \\ The senior lecturer of the Chair of English Grammar of Azerbaijan University of Languages \\ The Chair of English Grammar of Azerbaijan University of Languages \\ 60, Rashid Behbudov str, Az. 1014, Baku, Azerbaijan \\ Tel: 994-012-441-2279_E-mail: shalalahaliyeva@yahoo.com
}

\begin{abstract}
The article deals with the meanings of the English preposition "by" in the IX-XIX centuries and their Azerbaijani equivalents. During that period the preposition "by" had more than 10 variants of writing.

From the IX to the XIX centuries the preposition "by" was used in 6 main meanings: the meanings were connected with position, motion (or action), time, mental proximity, circumstances (condition, manner), medium (or means). Each of these meanings of the preposition "by" included a lot of small meanings or sub-meanings.
\end{abstract}

Keywords: Preposition, The English language, The Azerbaijan language, Meanings, Motion, Form, Variant, Means, Century, Word

\section{Introduction}

The article is devoted to the preposition "by" which is considered to be one of the main prepositions of the English Language. The theme of prepositions is very debatable in linguistics. As Azerbaijan was one of the former 15 Soviet Union republics, the viewpoints of Soviet scholars or linguists differed from those of the scholars and linguists of western countries. So, in the article one can see different viewpoints of Azerbaijani, Russian linguists or grammarians as well as western ones.

According to prof. Oruj Musayev, the great Azerbaijan scholar, in Modern English the parts of speech are divided into 3 groups. They are: notional parts of speech, structural parts of speech and independent parts of speech. The Russian scholars have approximately the same division, only with slight differences. The preposition is considered to be one of the structural parts of speech. It is a word relating to a group of words. Not having its lexical meaning and syntactical function in a sentence, the preposition is considered a structural part of speech.

In Modern English, from the morphological point of view, the category of case of the noun is weak and the preposition is used to express the grammatical relations which exist between nouns and other parts of speech.

The preposition is a structural part of speech and shows the relationship between two notions, not depending on that whether they are things, ideas or actions.

It is necessary to mention that in the Azerbaijan language there doesn't exist a part of speech called "preposition" and in the Azerbaijan language the relation between the nouns and other parts of speech are expressed by case suffixes and some other suffixes. These relations can also be expressed by some lexical means of expression.

\section{What is the Preposition?}

According to some foreign sources (especially I-net sources), in English there exist more than 150 prepositions, (even some sources say that their number is nearly 200) most of which are widely used in spoken language. The prepositions play an important role in the sentence, since without them the sentences would sound not only strange, but also they would acquire extremely confused meanings.

Prepositions are the words denoting the relation or connection between words, i.e. between nouns following them or other words in the sentence. In addition to all these, they don't change in number, gender and case. They precede nouns and pronouns and rarely stand before other words.

Accordingly, it seems that prepositions are always used before their objects. Though in most cases it happens like this, we must add that in many examples prepositions follow their objects. The object of the preposition, whether it is noun or pronoun, is usually in the objective case. In pronouns it reveals by the form of the word. The preposition may be defined as a linking word, denoting the relation of the noun or the noun substitute to another word in a sentence. These relations include: place, direction, time, manner and agent of the action.

So we can summarize the all characteristic features of the preposition like the following: 
1. Prepositions usually stand before nouns.

2. Prepositions can be used with all forms (types) of nouns (e.g. with collective nouns, with material nouns, with abstract nouns, etc.).

3. Prepositions are not joined with verbs, but they can be used before gerunds or verbs in the form of noun.

Besides nouns, objects can be expressed by:

1. Pronouns.

2. Adjectives.

3. Adverbs.

4. Phrases.

5. Non-finite forms of the verb (especially Gerunds).

6. Subordinate Clauses.

Prepositions are often joined with verbs, forming phrasal or composite verbs and such kind of prepositions are defined as postpositions.

Prepositions may consist of one word or a prepositional phrase, which functions as a whole unit. A preposition is always followed by a noun, which is the "object" of the preposition. Prepositions and their objects make prepositional phrases, which have the function of adverbial (adjective or adverb).

\subsection{Types of prepositions according to the meaning}

As it has already been mentioned, in English there exist more than 150 prepositions. According to the viewpoints of Russian and Azerbaijani grammarians the prepositions, according to their meaning, are divided into the prepositions of:

1. place. This type includes in, on, at, under, near, behind, by, etc. Most of the prepositions of place also express time when standing before the words denoting time: at, by, in, on, etc.

2. time: at, by, in, after, etc.

3. direction: to, into, towards, etc.

4. abstract relations: with, by, within, etc.

But the viewpoints of foreign scholars are quite different. They think that there exists another classification of prepositions. They find more than 30 types of prepositions, which include the prepositions of movement, means, comparison, cause, connection, measure and manner, standard, exception and addition, negative condition, reaction, concession, support and opposition, accompaniment, stimulus, source, origin, etc.

One of the main problems concerning the preposition in English is that some prepositions can express several different meanings. It would be useless to try to classify all the prepositions, since they differ very much in their meanings.

The biggest group of the prepositions includes the prepositions of place and time.

The following prepositions are considered the most widely-used prepositions in English: at, about, after, behind, by, between, in, into, of, off, on, out, to, towards, up, upon, with, within, etc.

But prepositions often become the cause of many problems, as only prepositions, in comparison with other parts of speech, can substitute one another in most cases, not taking into consideration the shade of meaning.

The most effective method of learning or mastering prepositions is learning the prepositions and remembering phrasal verbs through practice and memorizing. It is especially useful for bilingual students, for whom the use of prepositions seems to be one of the hardest parts of the English language.

\section{Means of expression of the English Preposition "BY"}

One of the most widely-known prepositions of Modern English is the preposition "by". Before speaking about the origin of the preposition "by" and its meanings in the Azerbaijan language, we should speak about some peculiarities of the Azerbaijan and English languages.

As is well known, the English language belongs to analytical languages group, but the Azerbaijan language does to synthetical languages group. Accordingly, different notions in the English language are mainly expressed by different words, but in the Azerbaijan language they are expressed mainly by synthetical elements, e.g. by means of affixes. 
According to the above mentioned views, the means of expression of the preposition "by" in Azerbaijan are divided into the followings:

1. Synthetical means, e.g. suffixes.

2. Analytical means, e.g. different words or parts of speech.

So, investigating the origin of the English prepositions, one can see that they coincide (or they are very alike) with the prepositions belonging to other languages. It is natural, as they may have been borrowed from other languages (OR maybe they had one and the same origin).

\section{The Meanings of "BY" in the IX-XIX Centuries with their Azerbaijani Equivalents}

It must be noted that approximately all prepositions possess more than one meaning. "By" is one of such prepositions. According to its meanings the preposition "by" is connected with 6 main notions or (leading) meanings.

1. with "position in space".

2. with "motion (or movement)".

3. with "time".

4. with "mental or ideal proximity".

5. with "medium, means, instrumentality, agency".

6. with "circumstances, condition, manner, cause, reason" (Chiefly developments or weakenings of earlier senses) (in general, stressed and weak (unstressed) forms of the previous meanings.

\subsection{The meaning of "position in space"}

The preposition "by" is interconnected with the "position in space" in the following meanings; around, about sth (= nəyinsa atrafinda/yanında), near (= nəyinsa kanarında/yaxınlığında), in, inside (= içərida, evda, daxilda), above the norm (= normadan çox); contrary, against, opposite (= əksinə, aleyhinə); far, in the distance (= uzaq, $u z a q d a)$, on the edge, on the brink (= kənar, kanarda); on sth (= üzarindo, $-d a^{2 *}$; by means of, by the help of $(=$ vasitəsila); alone, isolated (tək, tənha, tacrid olunmuş halda).

1. Ceolas stondað bi staðe fæste.

Cold winds continue(d) fast by the estate.

Malikanənin ətrafında tez-tez soyuq küləklər əsməyə başladı (başlayır).

2. Tyll she be stronge to goo by her-self.

Till she is strong enough to go by herself.

$\mathrm{O}$, təkbaşına getmək üçün kifayət qədər güclü olana qədər.

3. Pat engel... stod hemm bi.

That angel stood by him.

O mələk (çapar, kuryer) onun yanında durmuşdu.

\subsection{The meaning of "motion"}

The preposition "by" expressed the following meanings connected with the meaning "motion (or movement)"; along (= nayinsa boyunca, ila); near, next to (= yaxin, yaninda), till, to $(=$ qadər); at a distance of $(=\ldots$ masafada).

1. That came vs by and very near, Ascendynge vp into her hyghe sete.

That came us by and very near, ascending up into her high seat.

$\mathrm{O}$, o qadının hündür oturacağına qalxaraq, bizim yanımıza gəldi və daha

da yaxınlaşd1.

2. An angill come \& hem forbad To wend by hym [Herod] eny way.

An angel came and forbade him to go by him anyway.

Mələk gəldi və ona onun (Herodun) yanında getməyi qadağan etdi.

3. There is nother castel nor towne by $\mathrm{xx}$ myles nyghe aboute it. 
There is neither castel, nor town by xx miles near about it.

Yaxınlıqda xx mil məsafədə nə qəsr, nə də şəhər var.

\subsection{The meaning of "time"}

The preposition "by" expressed the following meanings connected with the meaning "time"; during, in, at (= arzində, müddatində; - $\left.d a^{2 *}\right)$, not later than (= gec olmayaraq), for (= üçün).

1. He ded shuld be, And ly in erthe by dayes thre.

He should be dead, and have lied on earth by three days (= for three days).

Gərək ki, o, ölüb, və 3 gündür ki, yerdə uzanıb qalıb.

2. He bryngib in newe [servants] pat done werse bi litil tym.

He brought in the new servant who has done worse by little time.

$\mathrm{O}$, az vaxt ərzində pis iş görmüş yeni qulluqçunu içəri gətirdi.

3. Heold Crist hiss fasste ... Bi dazhes \& bi nahhtess.

Crist held fast to the son (= young man, warrior) by days and by nights.

Krist gündüzlər və gecələr (ərzində) oğlunun (cavan insanın, döyüşçünün)

yanından əl çəkmirdi (ondan bərk yapışmışdı).

3.4. The meaning of "mental or ideal proximity"

The preposition "by" expressed the following meanings connected with the meaning "mental proximity": by the help of, with, according to; about, connected, in connection with, because of (= üçün, göra, sabəbindən), in view of (= nəzərə alaraq), in connection with, in connexion with (= alaqadar olaraq), in light of, owing to (= sabəbindən, göra), as a result of, on the grounds of (= sabəbindən, bəhanəsila, asasla); against, opposite (= əksinə); across the street/road/way (= küçənin/yolun o biri/əks tərəfində və ya küçəni/yolu keçdikdən sonra o biri tərafdə); on the contrary (= aksinə).

1. No such Merchand ... should put any Herring to Sale by Barrel,

Demy-Barrel, or Firkin.

Heç bir belə tacir gərək siyənək balığını çəlləklə (vasitəsilə), yarım-çəlləklə

və ya kiçik çəlləklə satışa qoymasın.

2. By means of their Brokers they buy by the great, and sell them againe by the piece.

By means of their Brokers they buy great portions and sell them again by pieces.

Onlar öz brokerləri vasitəsilə böyük hissələrlə alırlar və yenidən kiçik hissələrlə satırlar.

3. By him and by this woman heere, what know you?

What do you know in connexion with him and in connexion with this woman here?

O kişi və buradakı bu qadınla bağlı siz nə bilirsiniz?

3.5. The meaning of "medium, means, instrumentality, agency"

The preposition "by" expressed the following meanings connected with the meaning " environment, means, ways": from $\left(=-d a n^{2 *}\right)$; with $\left(=i l a,-l a^{2} *\right)$, under $(=a l t d a$, altunda); by means of, together with (= vasitasila, ila, ilo birgว).

1. Shephurdes by the seuen sterres Wisten ...whenne hit shoude reynen.

Shepherds knew (= learned) by means of seven stars when it should rain.

Çobanlar yeddi ulduz vasitəsilə yağışın nə vaxt yağacağını öyrənirdilər.

2. Brut... sones hadde pre $\underline{\text { By }}$ hys wyf.

Brut had three sons from his wife. 
Brutun öz arvadından 3 oğlu var idi.

3. Nether to be allurid by prommissis nor persuadid bi wurds.

Neither to be allured by promises, nor persuaded by words.

Nə vədlərlə ovsunlanmaq, nə də sözlərlə əmin edilmək (yola gətirilmək).

3.6. The meaning of "circumstances, condition, manner, cause, reason".

This meaning chiefly includes the developments or weakenings of earlier senses. In general, they are the stressed and weak (unstressed) forms of the previous meanings.

The preposition "by" expressed the following meanings connected with the meaning "circumstances, condition, cause (in general, stressed and weak (unstressed) forms of the previous meanings)": from ( $\left.=-d a n^{2 *}\right)$; with, in a manner, like (= $-d a^{2 *}$; tərzdo, halda, kimi); with, together with $\left(=i l \partial,-l a^{2 *}\right)$; because (of), on account of $(=$ sababindan, $\left.-d a n^{2 *}\right)$ :

1. Though flewme of himself $\underline{\text { be }}$ thicke and vnsauery by strengthe of heete.

Though his flame was thick (high) and it was unsavory because of the strength of heet.

Baxmayaraq, onun öz atəşi cox idi və istiliyin şiddətindən xoşagəlməz idi.

2. Me lihtede candles to æten $\underline{\mathbf{b i}}$.

I lighted the candle to eat by (the light of) it.

Mən şam işığında yemək yemək üçün onları yandırdım.

3. Be pam pe he fader is and laford he him self cwed be pe witie...

a) By them his father and the lord (master) himself is remarked on by the wise men.

Onun atasına və ağasına onlarla birlikdə müdrik insanlar tərəfindən irad tutulur.

b) By them his father is and the lord (master) himself is remarked on by the wise men.

Onun atası onların yanındadır (onlarla birlikdədir) və ağasına müdrik

insanlar tərəfindən irad tutulur.

4. By that hee cals him virum mortis, I may lawfully conclude, etc.

Because of that he calls him virum mortis (= dead man), I may lawfully

conclude, etc.

Bu səbəbdən o, onu virum mortis (ölmüş adam) adlandırır, mən hüquqi

baxımdan belə nəticəyə gələ bilərəm və s.

Besides all these meanings, the preposition "by" and some old forms of it exist and are still used in some expressions. For instance;

by cas (= by case), by guess, by, might, by, consequence, by force, by chance, by cause of,

by means of, by way of, by reason of, by virtue of, by the hands of, by no means, by that, by the by,

by one's self, by the way, by name, by particular, by occasion, by common, by ordinary, by metaphor, etc.

1. He vel of is palefrey, \& brec is fot bi cas.

He fell off his palfrey (horse) and broke his foot by case.

O, öz atından yıxıldı və təsadüfən ayağını sındırdı.

2. This Manna followed the Israelites whatsoeuer the earth was: and by name

in the wilderness.

This man followed the Israelites whatsoever the earth was: and by name

in the wilderness. ...

$\mathrm{Bu}$ insan İsrailliləri hansı torpaqda olursa olsun izlədi, və səhra adlanan yerdə ...

3. I am not speaking by metaphor and Asiatically.

Mən metafora vasitəsilə və asiyasayă̆ı danışmıram. 
4. He hathe us up lyfft By the means of hys sonne callyd Emanuell.

He had us guided by means of his son (called) Emanuell.

O, bizə öz Emanuel adlı oğlu vasitəsilə bələdçilik etdirdi.

5. The Parliament is adjoined by virtue thereof [the Comission].

Partlament Komissiya vasitəsilə onunla qonşuluq edir.

\section{Summary and Concluding Remarks}

As a conclusion, we must note that each of the meanings of the preposition "by" had several means of expression during the IX-XIX centuries. These means included other simple prepositions which were closer to the preposition "by" in meaning, some phrasal prepositions and some expressions. While looking through the meanings of the preposition "by" in Modern English, we can come across with such a fact that the preposition "by" still retains most of its old meanings.

When speaking about the expressions with "by", it should also be mentioned that approximately all of them are still in use in Modern English, but some of them had only slight changes, such as by cas, by one's self, etc.

When speaking about the Azerbaijani equivalents of the preposition "by", we should note that they consist of analytical and synthetical ones. So, one fact is evident that in the Azerbaijan language analytical equivalents form a greater layer than synthetical ones. Azerbaijani equivalents are expressed by case suffixes, notional (mainly adverbs) and secondary (helping) parts of speech, especially goshma which doesn't exist in other languages, including English.

\section{References}

Hüseynzadə Muxtar. (1973). Müasir Azərbaycan Dili (Modern Azerbaijan Language by M.Husseynzadeh). Part III. Morphology. Maarif. Baku. (291-303).

Xəlilov Buludxan. (2007). Müasir Azərbaycan dilinin morfologiyası (277-301). (The Morphology of Modern Azerbaijani by B.Khalilov). Part I. Baku.

Аксененко Б.Н. (1956). Предлоги Английского Языка. (Prepositions of the English Language by B.Aksenenko). (3-57, 104-115). Москва.

A Comprehensive Grammar of the English Language. (1987). Longman Group Limited. (657-715).

Celce-Murcia Marianne, Larsen-Freeman Diane. (1999). The Grammar Book. An ESL/EFL Teacher's Course. Heinle \& Heinle Publishers. (401-424).

Close R.A. (1979). A Reference Grammar for Students of English. Moscow. (24-27, 160-183).

Greenbaum Sydney. (1996). Oxford English Grammar. Oxford University Press. (159-163).

Huddleston R., Pullum Geoffrey K. (2005). The Cambridge Grammar of the English Language. (597-663).

Leech G., Cruickshank B., Ivanic R. (2001). English Grammar. Longman.

Musayev Oruj (2007). "Grammar of the English Language”. Baku. (317-327)

Expalnatory Dictionary of the Azerbaijan Language. (1964). Volumes I, II, III, IV. Baku.

W.W.Skeat. (1961). Etymological Dictionary of the English Language. Oxford.

The Oxford English Dictionary. (1961). A New English Dictionary on Historical Principles. (pp. 1228-1232).

The Oxford Dictionary of English Etymology. (1985). Edited by C.T. Onions. Oxford.

On-line etymological dictionary of the English Language

Гальперин И.Р. (1978). “Большой Англо-Русский Словарь”. (Russian-English Dictionary by I.Galperin). Volume I. Москва.

http://en.wikipedia.org/wiki/List_of_English_prepositions

www.english club.com (English prepositions listed. Josef Essberger).

www.englishprepositions.com

\section{Notes}

* (The number two denotes the same suffixes having two forms. For instance $-\mathbf{d a n} \mathbf{n}^{2}$ has one more form - -don ${ }^{2}$ ). The first one is added to the words having hard vowels, but the second one is added to the words with soft vowels. E.g. sọhorrdən - since morning, torpaqdan - from the ground. 